\title{
Rhizopus oligosporus Activity in Crude Extract and Powder Form to Reduce Aspergillus flavus and Aflatoxin Contamination in Corn
}

\author{
Kusumaningtyas $\mathrm{E}^{1^{*}}$, Masrianti $^{2}$, Fitrya $\mathrm{F}^{2}$ \\ ${ }^{1}$ Indonesian Research Centre for Veterinary Science, Jl RE Martadinata 30 Bogor \\ ${ }^{2}$ Faculty of Pharmacy, Pancasila University, Srengseng Sawah Jagakarsa Jakarta \\ E-mail: enikusuma@yahoo.com
}

(received 28-11-2019; revised 30-12-2019; accepted 30-12-2019)

\begin{abstract}
ABSTRAK
Kusumaningtyas E, Masrianti, Fitrya F. 2019. Aktivitas Rhizopus oligosporus dalam bentuk ekstrak kasar dan serbuk untuk menurunkan Aspergillus flavus dan aflatoksin pada jagung. JITV 24(4): 173-181. DOI: http://dx.doi.org/10.14334/jitv.v24i4.2078

Rhizopus oligosporus (RO) dalam bentuk kultur isolat diketahui dapat menurunkan kontaminasi kapang toksigenik Aspergillus flavus (AF) dan aflatoksin B1 pada pakan ayam. Aplikasi dalam bentuk kultur kurang efektif. Penelitian ini bertujuan untuk mengevaluasi aktivitas Rhizopus oligosporus (RO) dalam bentuk ekstrak dan inokulum untuk menurunkan kontaminasi AF dan aflatoksin B1 pada jagung. RO dipanen dari kultur agar, sebagian diekstrak dengan cara dihancurkan, ditambah air dengan perbandingan 1:1 (w/v) dan disentrifus. Supernatant disaring menggunakan kertas saring Whatman 41. Inokulum dibuat dengan menginokulasikan RO pada tepung kedelai dan diinkubasi pada suhu $28^{\circ} \mathrm{C}$ selama 5 hari. Inokulum dikeringkan pada suhu $40^{\circ} \mathrm{C}$ selama $24-48$ jam. Ekstrak dan inokulum masing-masing diuji aktivitasnya dengan menambahkankan pada jagung. Ekstrak diuji dengan perbandingan ekstrak dan jagung 1:1 (v/w), sedangkan inokulum ditambahkan pada jagung dengan dosis 5, 25, 50, 100 dan $200 \mathrm{~g} / \mathrm{kg}$ jagung. Pengujian kadar aflatoksin B1 dilakukan menggunakan kit ELISA aflatoksin. Hasil penelitian menunjukkan bahwa ekstrak RO dapat menurunkan kontaminasi AF hingga $1 \log 10$, sedangkan konsentrasi inokulum terendah yang dapat menghambat pertumbuhan AF hingga $6 \log 10$ adalah $100 \mathrm{~g}$ inokulum/kg jagung. Ekstrak RO 125 dan $250 \mathrm{~mL} / \mathrm{kg}$ jagung dapat menurunkan kontaminasi aflatoksin sebesar 93,69\% dan $85,84 \%$. Inokulum pada dosis 5 dan $100 \mathrm{~g} / \mathrm{kg}$ jagung dapat menurunkan konsentrasi aflatoksin sebesar 57,58\% dan 85,94\%. Berdasarkan hasil tersebut dapat disimpulkan bahwa RO dalam bentuk ekstrak maupun inokulum dapat menurunkan kontaminasi AF dan aflatoksin B1 pada jagung. Rhizopus dalam bentuk inokulum lebih mudah diaplikasikan daripada dalam bentuk ekstrak.
\end{abstract}

Kata Kunci: Aflatoksin, Aspergillus flavus, Ekstrak, Serbuk, Rhizopus oligosporus

\section{ABSTRACT}

Kusumaningtyas E, Masrianti, Fitrya F. 2019. Rhizopus oligosporus activity in crude extract and powder form to reduce Aspergillus flavus and aflatoxin in corn. JITV 24(4): 173-181. DOI: http://dx.doi.org/10.14334/jitv.v24i4.2078

Rhizopus oligosporus (RO) in isolate culture was known to reduce contamination toxigenic mold Aspergillus flavus (AF) and aflatoxin B1 in chicken feed. Application in culture form was not effective. The aim of this research was to evaluate RO activities in extract and inoculum form to reduce contamination of AF and aflatoxin B1 in corn. RO was harvested from agar plate, blended, added with water (ratio 1:1 (w/v)) and centrifuged. Supernatant was filtered using Whatman 41. Inoculum was made by inoculation $\mathrm{RO}$ in soy powder and incubated at $28^{\circ} \mathrm{C}$ for 5 days. Inoculum was dried at $40^{\circ} \mathrm{C}$ for $24-28$ hours. Assay was conducted by addition extract or inoculum to corn. Extract and corn ratio were 1:1 (v/w), while inoculum doses were 5, 25, 50, 1000 dan $200 \mathrm{~g} / \mathrm{kg}$ corn. Assay for aflatoxin B1 was done using kit ELISA aflatoxin. The result of this research showed that extract was able to reduce AF contamination up to $1 \log 10$, while the less concentration of inoculum which able to inhibit AF up to $6 \log 10$ was $100 \mathrm{~g} / \mathrm{kg}$ corn. Extract RO 125 and $250 \mathrm{~mL} / \mathrm{kg}$ corn was able to reduce aflatoxin contamination by $93.69 \%$ and $85.84 \%$. Inoculum at dose 5 and $100 \mathrm{~g} / \mathrm{kg}$ corn was able to reduce aflatoxin $57.58 \%$ and $85 \%$. Based on the result, it could be concluded that RO in extract or inoculum form was able to reduce contamination of AF and aflatoxin B1 in corn. Rhizopus as inoculum was easier to be applied than in extract form.

Key Words: Aflatoxin, Aspergillus flavus, Extract, Powder, Rhizopus oligosporus

\section{INTRODUCTION}

Aspergillus flavus is a toxigenic mold producing aflatoxin. This mold commonly grows in seeds and

main corresponding author: *enikusuma@ yahoo.com nuts. Aflatoxin is a carcinogenic substance which harmful to human health and cause reduction in animal production. Some technologies were applied to minimize aflatoxin exposure during pre and postharvest such as irradiation, ozone fumigation, chemical and biological control agent and improving packaging 
materials (Udomkun et al. 2017). However, these technologies may not sufficient to eliminate the fungal and toxin contamination (Ortega-Beltran et al. 2018), therefore it need to try new methods or agents. Bacteria and non-toxigenic fungi were commonly used for Aspergillus flavus biocontrol and aflatoxin degradation. Streptomyces yanglinensis 3-10 (Shakeel et al. 2018) and Bacillus subtilis UTBSP1 (Farzaneh et al. 2016) showed promising activity to control Aspergillus flavus in peanut kernel and pistachio nut. Non-toxigenic Aspergillus flavus (Ehrlich 2014) and Rhizopus stolonifer (Iqbal et al. 2014) as mycelium or extract inhibited Aspergillus flavus growth. Non-toxigenic fungus competes with close related strain to meet nitrogen, carbon, water and mineral (Ehrlich 2014). Rhizopus oligosporus (BCC F0216), Saccharomyces cerevisiae (BCC F0206) (Kusumaningtyas et al. 2006), Rhizopus oryzae (CCT 7560) and Trichoderma reesei (QM9414) (Hackbart et al. 2014) were also reported as biological control for Aspergillus flavus or aflatoxin.

Direct application of Rhizopus oligosporus in chicken feed was reported able to inhibit growth of Aspergillus flavus and reduce aflatoxin production up to 15 days (Kusumaningtyas et al. 2006). Addition of Rhizopus oligosporus in duck feed reduced aflatoxin B1 and M1 residue in duck liver (Kusumaningtyas et al. 2006b). Direct application of Rhizopus oligosporus culture from agar plate was not effective, especially in field. Mixing Rhizopus oligosporus in rice powder was reported able to maintain viability of Rhizopus $100 \%$ in 60 days (Kusumaningtyas et al. 2005). In this research was tried to used soy powder to replace rice powder. Soybean is not only rich in protein, but also contains almost all essential and non-essential amino acids. Besides, soybean less expensive than animal protein. Fermentation increases protein and fats content and decreases carbohydrates, increase small size peptides ( $<15 \mathrm{kDa})$, improved amino acids essential and reduced anti-nutritional substance in soy (Mukherjee et al. 2016). Inoculum was made by growing Rhizopus oligosporus in soy powder. The dry inoculum was applied in corn to reduce aflatoxin contamination. The result was compared to Rhizopus oligosporus extract. This study was done to evaluate Rhizopus oligosporus in extract and inoculum form to reduce Aspergillus flavus and aflatoxin contamination in corn.

\section{MATERIALS AND METHODS}

\section{Microorganism}

Rhizopus oligosporus (BCC F0216) and Aspergillus flavus (BCC F0213) were obtained from BBlitvet Culture Collection.

\section{Culturing and propagating microorganism}

Rhizopus oligosporus (BCC F0216) and Aspergillus flavus (BCC F0213) were grown in Sabouraud dextrose agar (SDA), incubated at $28^{\circ} \mathrm{C}$ for 3 days. Fresh cultures were then used directly for assays.

\section{Extraction of Rhizopus oligosporus}

Rhizopus oligosporus (RO) from Sabouraud dextrose agar (SDA) media was harvested by scrapping mold, put into new flask and suspended with $7.5 \mathrm{~mL}$ phosphate buffer saline (PBS) per petri dish. Suspension was blend, homogenized and then centrifuged at $6000 \mathrm{xg}$ for 15 minutes. Supernatant was taken and then filtered through $0.45 \mu \mathrm{m}$ membrane. Filtrat was collected in the new tube. Filtrat was applied diretly for assay or storage at $-20^{\circ} \mathrm{C}$ until used. Filtrat might contain secondary metabolite, protein, enzyme and other soluble compound.

\section{Soybean powder preparation}

Dry soybean was ground until it become flour. The flour was sterilized by autoclaving at $121^{\circ} \mathrm{C}, 1 \mathrm{~atm}$ for 20 minutes (WHO 2019).

\section{Rhizopus oligosporus Inoculum}

Rhizopus oligosporus (RO) was grown on the SDA media and incubated at $28^{\circ} \mathrm{C}$ for 3 days. RO was harvested and suspended in PBS until reach $10^{6}$ spores $/ \mathrm{mL}$. As much $250 \mathrm{~mL}$ spore suspension was added into $500 \mathrm{~g}$ sterile soybean flour, homogenized and then incubated at $28^{\circ} \mathrm{C}$ for 3 days. Inoculum was stirred every day to ensure homogeneity. After 3 days incubation, inoculum was divided into two part. Once was without treatment, namely wet inoculum, and used for assay directly. Another part was dried at $40^{\circ} \mathrm{C}$ overnight or until dried, namely dried inoculum. Killed inoculum was made by autoclaved the inoculum at 1 atm, $121^{\circ} \mathrm{C}$ for 20 minutes.

\section{Corn contaminated by Aspergillus flavus}

Ground corn was sterilized by autoclaving at $121^{\circ} \mathrm{C}$, 1 atm for 20 minutes. Aspergillus flavus (AF) was prepared by growing in SDA medium, incubated at $28^{\circ} \mathrm{C}$ for 3 days. Spores were collected by scraping and suspended in sterile PBS. The suspension was diluted to obtained spore concentration $10^{6}$ spores $/ \mathrm{mL}$. As much $10 \mathrm{~mL}$ AF spore suspension was added into $250 \mathrm{~g}$ sterile corn, homogenized and then incubated at $28^{\circ} \mathrm{C}$ for 3 days. 
Effect of Rhizopus oligosporus extract on growth of Aspergillus flavus in corn

RO extract was mixed with corn contaminated by $A$. flavus in various concentrations: $10^{6}, 10^{5}, 10^{4}, 10^{3}, 10^{2}$ $\mathrm{CFU} / \mathrm{g}$ with ratio $1: 1(\mathrm{v} / \mathrm{w})$, incubated at room temperature for 2 hours. The mixture was taken 1 gram diluted with physiological $\mathrm{NaCl}$ until the volume reached $10 \mathrm{~mL}$. Serial dilution was made from $10^{-1}$ to $10^{-6}$. The $1 \mathrm{~mL}$ suspension was poured in SDA medium $\left( \pm 50^{\circ} \mathrm{C}\right)$ and let the medium hardened. The plates were incubated at $28^{\circ} \mathrm{C}$ for 3 days (Ahmed et al. 2016). The colony grown was counted and recorded.

Effect of killed inoculum of Rhizopus oligosporus in Aspergillus flavus growth

As much as $100 \mathrm{~g}$ killed inoculum was added to the $1 \mathrm{~kg}$ corn contaminated with $\mathrm{AF}$ which was made previously, incubated in room temperature for 2 hours. As much as $1 \mathrm{~g}$ of the mixture was taken and diluted with physiological $\mathrm{NaCl}$ until the volume reached 10 $\mathrm{mL}$. Serial dilution was made from $10^{-1}$ to $10^{-6}$. The 1 $\mathrm{mL}$ suspension was poured in SDA medium $\left( \pm 50^{\circ} \mathrm{C}\right)$ and let the medium hardened. The plates were incubated at $28^{\circ} \mathrm{C}$ for 3 days. The colonies grown were counted and documented.

Effect of wet and dried of live inoculum activity in Aspergillus flavus growth

Each of wet and dried inoculum $100 \mathrm{~g}$ was added to $1 \mathrm{~kg}$ corn contaminated with $\mathrm{AF}$ and incubated at $28^{\circ} \mathrm{C}$ for 3 days. As much as $1 \mathrm{~g}$ of each mixture was taken and diluted with physiological $\mathrm{NaCl}$ until the volume reached $10 \mathrm{~mL}$. Serial dilution was made from $10^{-1}$ to $10^{-6}$. The $1 \mathrm{~mL}$ suspension was poured in SDA medium $\left( \pm 50^{\circ} \mathrm{C}\right)$ and let the medium hardened. The plates were incubated at $28^{\circ} \mathrm{C}$ for 3 days. The viable colonies were counted and documented. Corn contaminated with AF without treatment was used as control.

\section{Effect of concentration of dried Rhizopus inoculum on Aspergillus flavus reduction in corn}

RO inoculum was prepared in sterile flask containing: 5 g, 25 g, 50 g, 100 g, 50 g and 200 g. Each inoculum was mixed with $1 \mathrm{~kg}$ corn contaminated which previously contaminated by Aspergillus flavus (AF). Corn contaminated (AF) without inoculum addition was used as negative control. All treatments were done in three replications. Each mixture was incubated at $28^{\circ} \mathrm{C}$ for 3 days. After 3 days incubation, 1 $\mathrm{g}$ mixture was taken and suspended in $9 \mathrm{~mL}$ physiological $\mathrm{NaCl}$. Serial dilution was made from $10^{-1}$ to $10^{-6}$. The $1 \mathrm{~mL}$ suspension was taken and inoculated in SDA medium using pour plate methods. The plates were incubated at $28^{\circ} \mathrm{C}$ for 3 days. The colony grown was counted and documented.

\section{Effect of inoculum on growth of Aspergillus flavus during certain period}

As much as $100 \mathrm{~g}$ RO inoculum was mixed with $1000 \mathrm{~g}$ corn contaminated with A flavus. One $\mathrm{g}$ of the mixture was taken at day $0,1,2,3,4,5,6,7,8$. Corn contaminated with $A$. favus without inoculum addition was used as negative control. The $1 \mathrm{~g}$ of the mixture was suspended in $9 \mathrm{~mL}$ physiological $\mathrm{NaCl}$. Serial dilution was made from $10^{-1}$ to $10^{-6}$. The $1 \mathrm{~mL}$ suspension was inoculated in SDA medium using pour plate methods. The plates were incubated at $28^{\circ} \mathrm{C}$ for 3 days. The colony grown was counted and documented.

\section{ELISA for Aflatoxin}

Aflatoxin extraction was conducted by taken $25 \mathrm{~g}$ corn treated previously, added with $100 \mathrm{~mL}$ ethanol $70 \%$, shaken for 30 minutes and then filtered. Filtrat was transferred in new tube. Aflatoxin ELISA kit (BBLitvet) was conditioned at room temperature for 1530 minutes. Aflatoxin B1 standard $40 \mu \mathrm{L}$ with concentration: $0,0.12,0.37,1.1,3.3,10,30 \mathrm{ppb}$ and extract: negative control (corn treated with A flavus without RO inoculum), sample 1 (corn treated with RO extract with ratio $1: 1(\mathrm{~g} / \mathrm{mL})$, sample 2 (corn with inoculum $50 \mathrm{~g} / \mathrm{kg}$ corn) and sample 3 (corn with inoculum $200 \mathrm{~g} / \mathrm{kg}$ ) was put in the microplate. Each plate was added with $120 \mu \mathrm{L}$ conjugate AFB1-HRP and mixed well. The mixture was taken $60 \mu \mathrm{L}$ for each microplate well and move to new microplate coated with antibody to aflatoxin B1. The plate was shaken to ensure all mixed well. Plate was incubated room temperature for 30 minutes. All suspension were removed and washed 3 times. Tetramethylbenzidine was added to each well and let it around 15 minutes until form blue colour. Stop solution was added to stop reaction until form yellow color. The plate was read at wavelength $450 \mathrm{~nm}$ in microplate reader. Aflatoxin concentration was calculated based on standard curve. Percentage of inhibition was calculated based on:

$$
\mathbf{y}=\mathbf{a} \ln X+\mathbf{b}
$$

$\mathrm{y}=\%$ inhibition of sample; $\mathrm{a}=\mathrm{a}$ slope $\mathrm{b}=$ intercept;

$\mathrm{X}=$ sample concentration 


\section{RESULTS AND DISCUSSION}

Rhizopus oligosporus was added to corn as extract and live inoculum in wet and dried form. Wet and dried inoculum were assayed for viability before used. It showed that they still viable even after drying process.

\section{Effect of Rhizopus oligosporus (RO) extract on growth of Aspergillus flavus (AF) in corn}

RO extract was added to ground corn in different concentration of AF contamination. This treatment was performed to determine the effectivity of the extract to decrease of A. flavus contamination. As shown at Figure 1, RO extract worked well in maximum AF concentration $10^{3} \mathrm{CFU} / \mathrm{g}$ with reducing value around 1 $\log$ cycle. When live culture of RO was added to chicken feed contaminated by AF, it was able to inhibit $\mathrm{AF}$ growth by competition mechanism (Kusumaningtyas et al. 2006). RO grew faster and compete to take mineral source with $\mathrm{AF}$ therefore Af was inhibited. In this research, the use of extract was proposed to evaluate that was only competition or RO produce certain metabolites which able to inhibit growth of AF.

As shown in Figure 1, AF inhibition was not only caused by competition but also metabolite produced by RO. Extract did not contain RO micelia due to membrane filtration but the extract still able to reduce $\mathrm{AF}$, especially when $\mathrm{AF}$ in $\leq 10^{3} \mathrm{CFU} / \mathrm{g}$. The extract might contain celuler or extracellular metabolite which able to inhibit AF. Although RO metabolite has not been reported, Lanciotti \& Guerzoni (1993) was revealed that the similar genus Rhizopus arrhizus produced metabolites such as ethanol, isobutilalcohol and 3-metil butanol which was able to inhibit AF growth. Rhizopus oryzae produce secondary metabolite methyl eugenol which showed inhibition of AF colonization and aflatoxin production on peanut and kernel (Faisal \& Prasad 2016). Kobayasi et al. (1992) reported that RO produced protease which cut proteins into peptides and also inhibited $\mathrm{AF}$ growth.

$\mathrm{RO}$ extract showed good in AF growth inhibition in $\mathrm{AF}$ concentration $\leq 10^{3} \quad \mathrm{CFU} / \mathrm{g}$ (Figure 1). In concentration $\geq 10^{4} \mathrm{CFU} / \mathrm{mL}$, the ability of RO extract to inhibit $\mathrm{AF}$ growth much decreased might be the metabolite did not enough to kill in higher concentration. Decreased activity could occur due to metabolite concentration constant but AF concentration increased or the metabolite decreased and AF constant. Similar case was shown by antifungal activity of secondary metabolite of Trichoderma koningii IABT 1252 'S. Antifungal activity of the metabolite decreased simultaneously with reduction of metabolite concentration (Rabinal \& Bhat 2017).

\section{Comparison of extract and killed RO inoculum activity in Aspergillus flavus growth}

The metabolite released by RO assumed that was able to stable although the RO was killed or it mass was removed. This may the metabolite present both in extract and killed inoculum. Comparison of extract or killed inoculum activity in AF growth was described in the Figure 2.

The activities of extract and killed RO inoculum to inhibit AF growth seem not different. Their inhibition less than one log cycle that means extract or killed inoculum only decrease $\mathrm{AF}$ from $10^{6} \mathrm{CFU} / \mathrm{g}$ to $10^{5}$ $\mathrm{CFU} / \mathrm{g}$. It means that the extract or inoculum activity to inhibit AF growth was low. As mentioned previously, RO extract very low activity to inhibit AF in AF concentration more than $10^{3} \mathrm{CFU} / \mathrm{g}$. The important substance might be released to extracellular but degraded during extraction process. Blending process might destruct the active compound. For example, the active substance which expected able to degrade aflatoxin was inactivated by intracellular enzyme. Intracellular enzyme was released during crushing and blending process. In addition, Filtration might cause active substance trapped in the filter and did not present in the filtrate. In killed inoculum, the substance might be degraded due to high temperature and pressure.

\section{Comparison of wet and dried of live inoculum activity in Aspergillus flavus growth}

Rhizopus oligosporus (RO) extract, wet and dried inoculum were prepared for further assay (Figure 3a and $3 b$ ). Dried inoculum in powder form easier to be mixed with corn than wet inoculum. To evaluate that live inoculum was able to inhibit AF growth was conducted by assayed wet and dried inoculum. Drying process was performed to simplify application and did by oven drying at $40^{\circ} \mathrm{C}$ to avoid substance disruption.

As shown at Figure 4, there is no different result between wet and dried inoculum to inhibit AF. They were able to reduce Aspergillus flavus (AF) up to $6 \log$ cycle CFU $/ \mathrm{mL}$. This proves that both wet and dried inoculum were able to be applied to reduce $\mathrm{AF}$ in ground corn. Comparison this result with previously performance in extract and killed inoculum showed that the active substance to inhibit $\mathrm{AF}$ was present in live Rhizopus. The substance might be damage when Rhizopus was extracted or killed. Nout (1989) reported that Rhizopus and Neurospora spp which inoculated simultaneously in mashed groundnuts were able to inhibit growth of Aspergillus flavus. Aspergillus spp were able to grow but lesser extend and visually different mycelial development and sporulation behavior. 


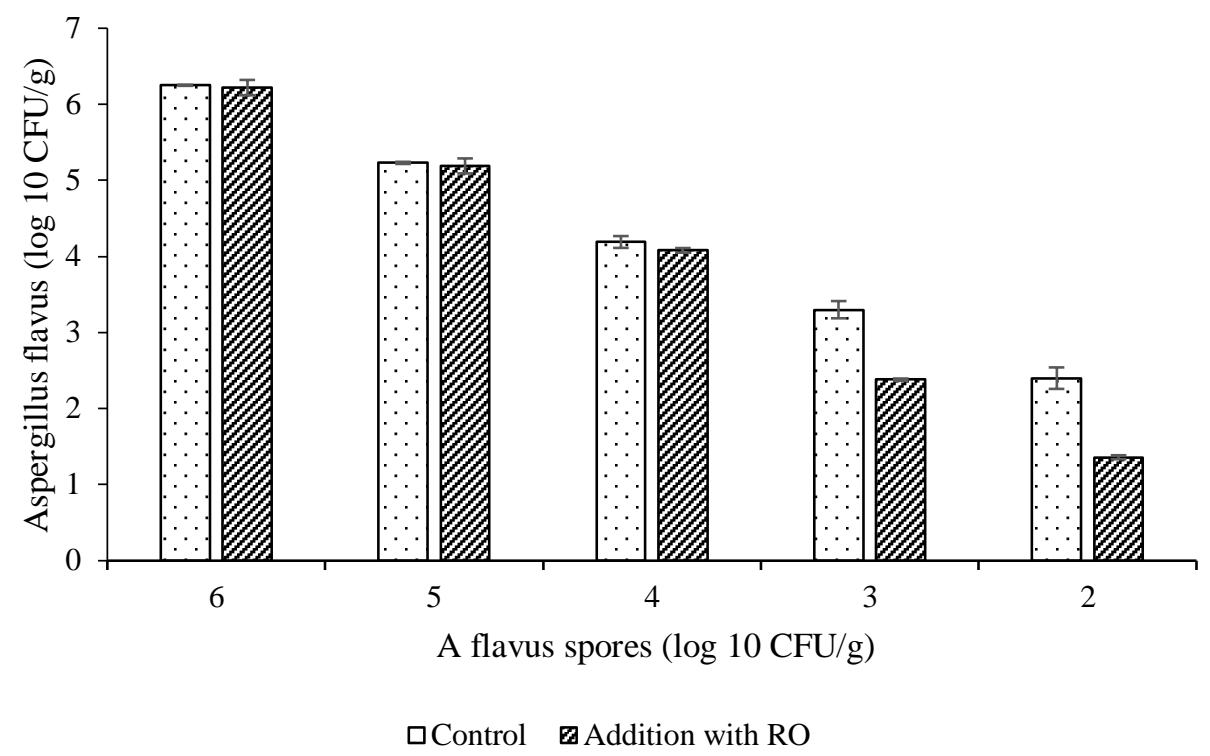

Figure 1. The ability of Rhizopus oligosporus extract to reduceAspergillus flavus contamination in corn

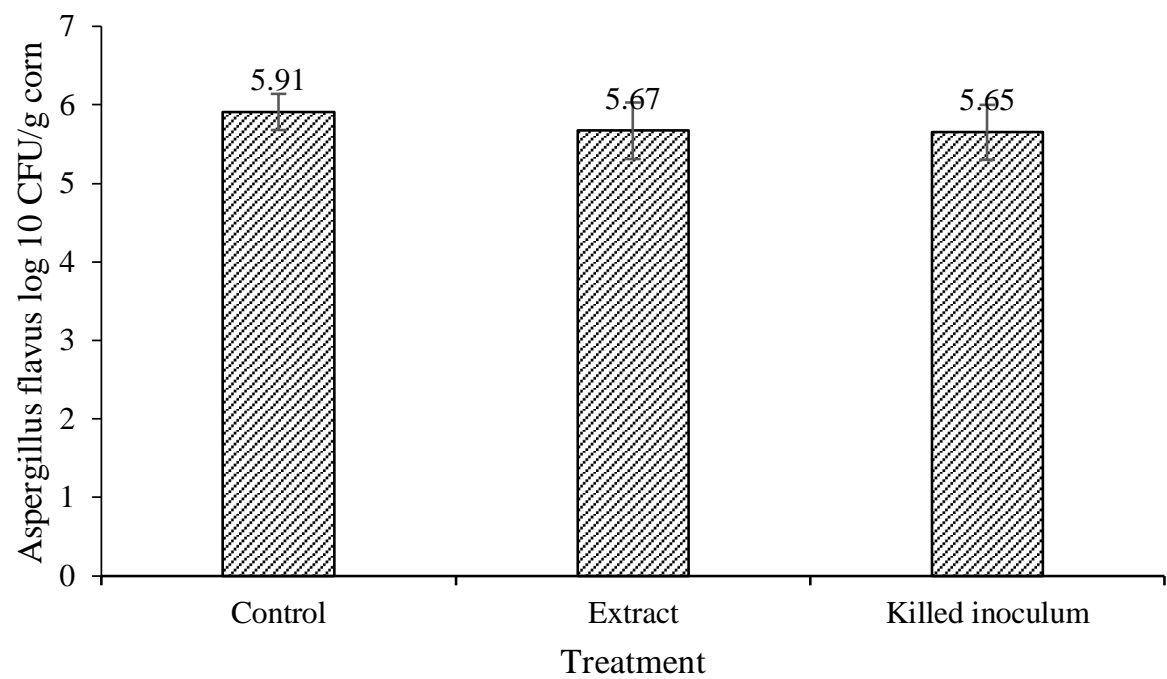

Figure 2. Comparison of the activities of extract and killed inoculum activities to inhibit Aspergillu flavus

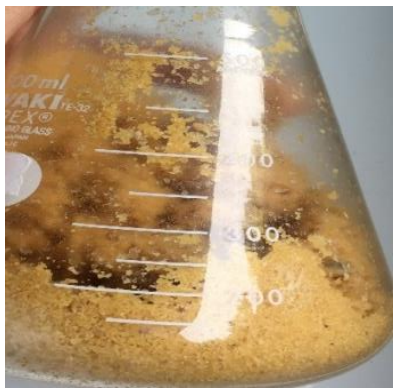

a

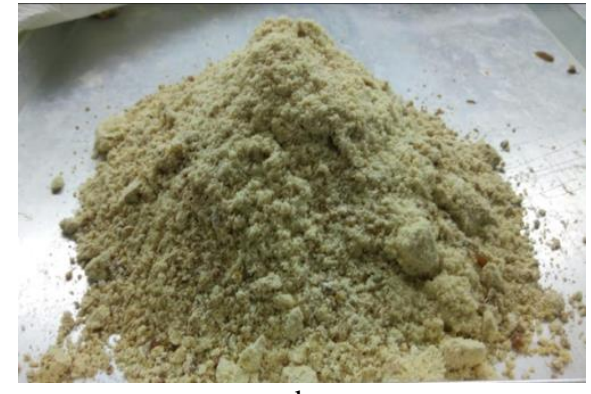

b

Figure 3. Wet (a) and dried (b) inoculum of Rhizopus oligosporus 


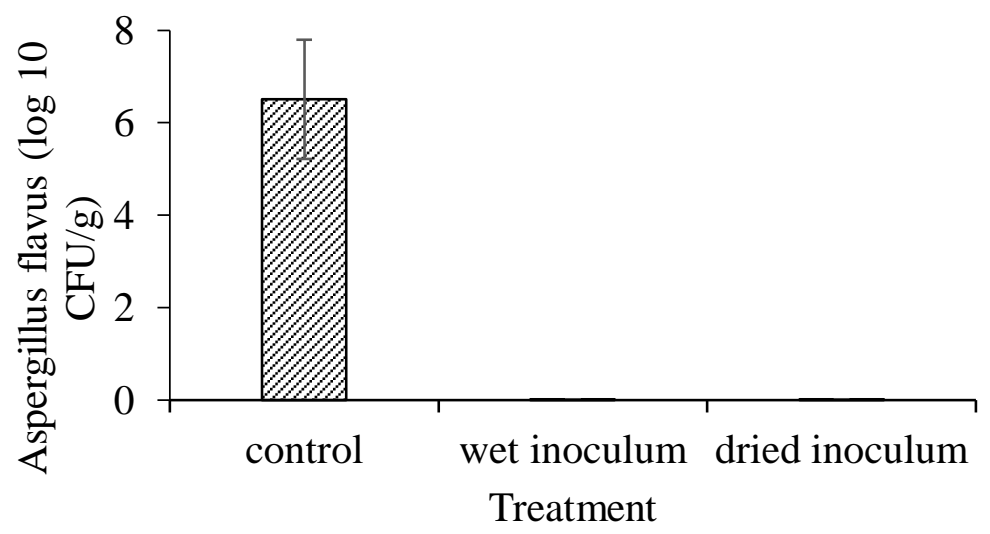

Figure 4. Comparison of the activities of wet and dried inoculum to inhibit Aspergillus flavus

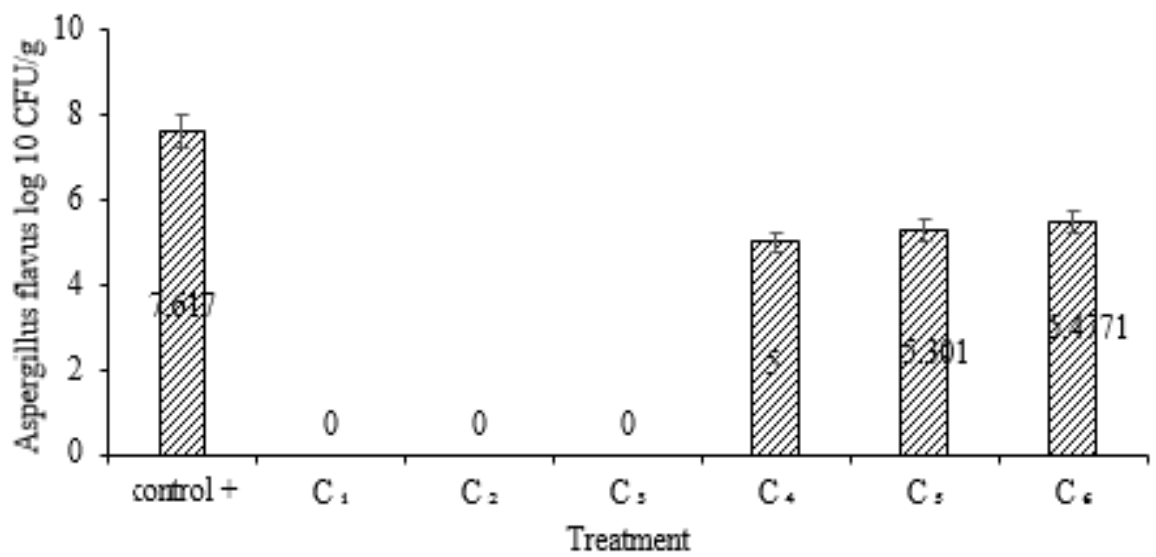

Figure 5. The effect of dried Rhizopus oligosporus inoculum in various concentration. Control: $1 \mathrm{~kg}$ corn contaminated Aspergillus flavus without any treatment and in the treatment the contaminated corn were added with dried inoculum C1: 200g, C2: 150 g, C3: $100 \mathrm{~g}$, $\mathrm{C} 4: 50 \mathrm{~g}, \mathrm{C} 5: 25 \mathrm{~g}$ and $\mathrm{C} 6: 5 \mathrm{~g}$

Rhizopus produces metabolite such as $\mathrm{C}$ compound which inhibit Aspergillus growth. Previously, although the Rhizopus extract was also from live Rhizopus, extraction process inactivated active compound. It is also possible that the antifungal substance which active to inhibit AF, present in RO mycelia. Fungal secondary metabolites produced and released from asexual conidia and sexual fruiting body structure (Doll et al. 2013). Antifungal substance in dried inoculum was stable and not degraded in $40^{\circ} \mathrm{C}$ oven drying. Dried inoculum was also more applicable in field due to its form. Powder form was easier to be mixed with food or feed stuff like corn or chicken feed than wet form.

\section{The effect of concentration of dried RO inoculum on AF reduction in corn}

Dried Rhizopus inoculum in various concentrations was applied in ground corn. It was used $200 \mathrm{~g}, 150 \mathrm{~g}$, $100 \mathrm{~g}, 50 \mathrm{~g}$ and $5 \mathrm{~g}$ per $\mathrm{kg}$ corn. The result was shown in Figure 5. The inoculum performed well in concentration
200,150 and $100 \mathrm{~g} / \mathrm{kg}$ corn indicated by reduction of Aspergillus flavus (AF) from $7.617 \log 10 \mathrm{CFU} / \mathrm{g}$ to 0 . In dose $50 \mathrm{~g} / \mathrm{kg}$ reduction only around $2 \mathrm{log}$ cycle. However, reduction AF activity among dose 50g, 25g and $5 \mathrm{~g}$ did not much different. The reduction decreased along with reduction of inoculum dose. Therefore, application of inoculum to reduce AF contamination is dose dependent. In addition, minimal dose which applicable in field was not less than $100 \mathrm{~g} / \mathrm{kg}$ to obtained sufficient result.

This result need further research to apply the inoculum in field. Preliminary study done previously showed that application inoculum in powder form producing better result than granule. Powder form mixed better in chicken feed. Granule form tend to settle in the bottom of the flask. Small size particle of powder made it easier to interact to food or feed surface contaminated by AF.

Critical point in the application of RO inoculum was mixing process beside the dosage. Amount of corn which would be added with inoculum determined the 


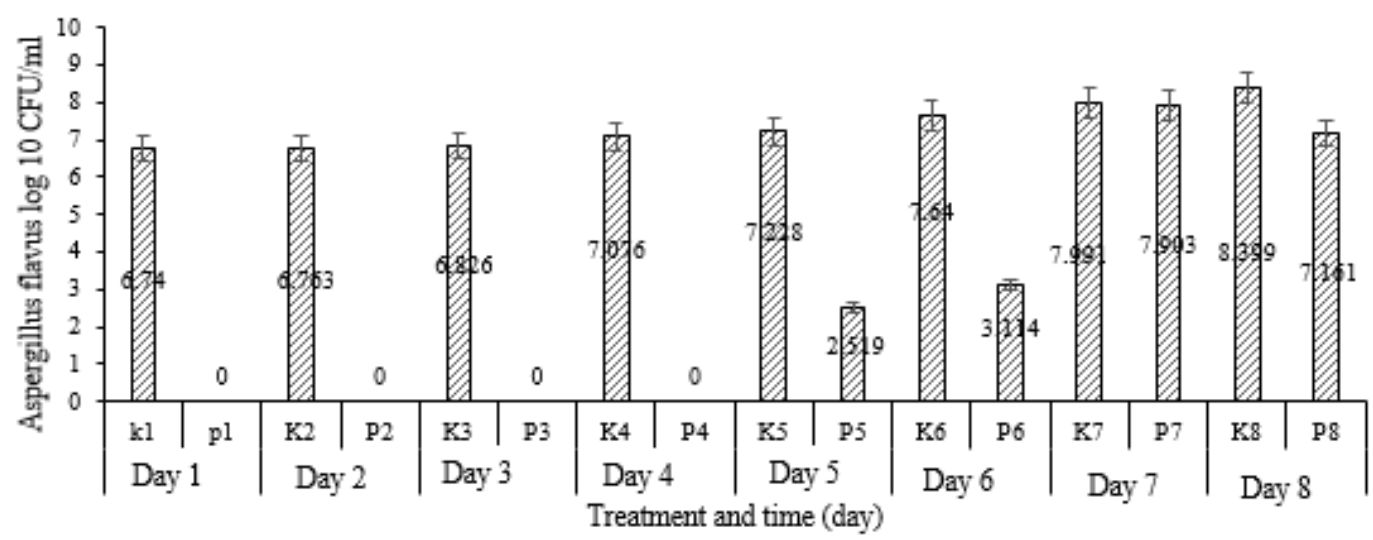

Figure 6. The effect of dried Rhizopus oligosporus inoculum $100 \mathrm{~g} / \mathrm{kg}$ contaminated corn in 8 days observation

quality of mixing process and reducing $\mathrm{AF}$ contamination. For example, mixing in $1 \mathrm{~kg}$ corn was easier than $100 \mathrm{~kg}$ corn and it increase reducing $\mathrm{AF}$ activity.

\section{The effect of $\mathrm{RO}$ inoculum to reduce $\mathrm{AF}$ certain period of time}

Dried inoculum dose $100 \mathrm{~g} / \mathrm{kg}$ was the lowest concentration resulting sufficient result. The following treatment was application of $\mathrm{RO}$ inoculum in ground corn with dose $100 \mathrm{~g} / \mathrm{kg}$ and stored for 8 days. AF reduction was observed and evaluated every day. The inoculum reduced $\mathrm{AF} 100 \%$ in 4 days incubation. At day $5 \mathrm{AF}$ grew around $2 \log 10 \mathrm{CFU} / \mathrm{g}$ and tend to increase every day. Based on this data, corn or other food or feed stuff contaminated with $\mathrm{AF}$ around $10^{7}$ $\mathrm{CFU} / \mathrm{g}$ and treated with RO inoculum better consumed before 5 days. Food and feed contaminated $\mathrm{AF}$ at previous dose without RO inoculum do not allowed for consumption both by animal and human. The effect of dried RO inoculum $100 \mathrm{~g} / \mathrm{kg}$ contaminated corn in 8 days observation was shown in Figure. 6.

\section{Reduction aflatoxin contamination in corn by extract and dried RO inoculum}

The FDA guidelines based on maintaining performance and avoiding disease related to aflatoxin mentioned that aflatoxin level in corn for young animal and dairy cattle must less than $20 \mathrm{ppb}$, corn for breeding beef cattle swine and mature poultry less than $100 \mathrm{ppb}$, corn for finishing swine and finishing cattle less than 200 and 300 ppb (FDA 2016).

Specific microbial metabolites showed strong activities to inhibit aflatoxin production. A number of Lentinula edodes isolates was able to inhibit aflatoxin production. This is possible that different compound needs different strategies to obtain optimum activity. A number of metabolites or filtrates increase their activities after fractionation, but fractionation of $L$ edodes CF42 filtrates decrease their inhibitory effect (Tian \& Chun 2017).

RO extract, wet and dried inoculums were able to reduce and inhibit growth of $\mathrm{AF}$ in corn. In the following step was measurement aflatoxin B1 as a secondary metabolite of AF with or without treatment with extract and dried Rhizopus inoculum. Aflatoxin B1 concentration measurement was conducted using ELISA methods and the results were shown in Table 1.

As shown in the Table 1, Rhizopus oligosporus (RO) both extract and dried inoculum were able to reduce aflatoxin contamination in corn. Reduction aflatoxin production might be due to inhibition of Aspergillus flavus (AF) growth which cause decreasing aflatoxin production. It is also possible that RO metabolites bound and degraded aflatoxin resulting reduction of measured aflatoxin. Although $\mathrm{RO}$ in extract form only inhibit AF less than $1 \mathrm{log}$ cycle in ratio $1: 1(\mathrm{v} / \mathrm{w})$ (Fig 3.) but it was able to reduce aflatoxin up to $93.69 \%$ in ratio 1:4 (v/w) (Table 1). This might the RO soluble metabolites in extract less activity to inhibit AF growth but active to reduce aflatoxin contamination in corn. Consider that incubation time for extract to react with $\mathrm{AF}$ and aflatoxin for 2 hours, it is possible that the RO metabolites was act as toxin binder or degraded aflatoxin which already present in corn resulting reduction in aflatoxin measurement.

Dried inoculum contained life RO which may also grow and compete with AF cause AF inhibition and aflatoxin reduction. Other species, Rhizopus nigricans which coculture with aflatoxin producer fungi, Aspergillus parasiticus was reported to inhibit aflatoxin production (El-Shiekh et al. 2007). Nout (1989) also 
Table 1. Reduction of Aflatoxin B1 concentration in corn treated with Rhizopus oligosporus extract and dried inoculum

\begin{tabular}{lccc}
\hline \hline No & Treatment & Aflatoxin B1 (ppb) & $\begin{array}{c}\text { Reducing Aflatoxin B1 } \\
(\%)\end{array}$ \\
\hline 1 & Control contaminated corn without treatment & 30.44 & - \\
2 & $250 \mathrm{~mL}$ Rhizopus oligosporus extract/ kg contaminated corn & 1.92 & 93.69 \\
3 & $125 \mathrm{~mL}$ Rhizopus oligosporus extract/ kg contaminated corn & 4.31 & 85.84 \\
4 & $100 \mathrm{~g}$ Rhizopus oligosporus inoculum/ kg contaminated corn & 4.28 & 85.93 \\
5 & $50 \mathrm{~g}$ Rhizopus oligosporus inoculum/ kg contaminated corn & 12.91 & 5759 \\
\hline
\end{tabular}

revealed that Rhizopus and Neurospora spp produce metabolite C compound which inhibited Aspergillus flavus, aflatoxin production and degraded aflatoxin Other possible mechanism was the live RO also produce metabolites which bound and degraded aflatoxin beside AF growth inhibition. Consider that aflatoxin is toxic metabolite of $\mathrm{AF}$, reduction of aflatoxin contamination was very important. Although RO extract also reduce aflatoxin but more difficult to be applied in field due to its liquid form, therefore dried inoculum is the most suitable form for RO application in food and feed stuff.

\section{CONCLUSION}

Rhizopus oligosporus in crude extract, wet inoculum and dried inoculum were able to inhibit Aspergillus flavus growth. Wet and dried inoculum inhibit Aspergillus flavus growth better than extract. Wet and dried inoculum had similar activity to inhibit Aspergillus flavus growth but the dried (powder) form easier to be mixed and applied in food or feed stuff. Extract and powder form of RO were also able to reduce aflatoxin B1 contamination in corn. The dried or powder form of RO was the most suitable form for application RO in field.

\section{ACKNOWLEDGEMENT}

We thank to Indonesian Research Institute for Veterinary Science for providing the research facility. The research was funded by Ministry of Agriculture Indonesia APBN 2019 No 1806.202.052.A

\section{REFERENCES}

Ahmed MM, Fakrudin Md, Hossain MdN, Mahbub KR, Choudhury A. 2016. Growth response of Aspergillus flavus IMS1103 isolated from poultry feed. Asian J Med Biol Res. 2:221-228.

Doll K, Chatterjee S, Scheu S, Karlovsky P, Rohlfs M. 2013. Fungal metabolic plasticity and sexual development mediate induced resistance to arthropod fungivory. Proc Biol Sci. 280:20132019.

Ehrlich K. 2014. Non-aflatoxigenic Aspergillus flavus to prevent aflatoxin contamination in crops: Advantages and limitations. Front Microbiol. 5:1-9.

El-Shiekh HH, Mahdy HM El-Aaser MM. 2007. Bioremediation of aflatoxins by some reference fungal strains. Pol J Microbiol. 56:215-223.

Faisal MP, Prasad L. 2016. A potential source of methyleugenol from secondary metabolite of Rhizopus oryzae 6975. Int J Appl Biol Pharm. 7:187-192.

Farzaneh M, Shi ZQ, Ahmadzadeh M, Hu LB, Ghassempour A. 2016. Inhibition of the Aspergillus flavus Growth and Aflatoxin B1 Contamination on Pistachio Nut by Fengycin and Surfactin-Producing Bacillus subtilis UTBSP1. Plant Pathol J. 32:209-215.

[FDA] Food and Drug Administration. 2016. CVM Annual Report on Mycotoxins in Animal Food Report for Fiscal Year 2016 (FY16). Washington DC (USA).

Hackbart HCS, Machado AR, Christ-Ribeiro A, Prietto L, Badiale-Furlong E. 2014. Reduction of aflatoxins by Rhizopus oryzae and Trichoderma reesei. Mycotoxin Res. 30:141-149.

Iqbal CM, Amin M, Iqbal Z, Bibi H, Iqbal A, Din Z, Suleman M SH. 2014. Antimicrobial, Cytotoxic and Phytotoxic Potency of Ethyl Acetate Extract of Rhizopus stolonifer. Trop J Pharm Res. 13:87-92.

Kobayasi S, Okazaki N, Koseki T. 1992. Purification and characterization of an antibiotic substance produced from Rhizopus oligosporus IFO 8631. Biosci Biotechnol Biochem. 56:94-98.

Kusumaningtyas E, Widiastuti R, Istiana, Maryam R, Tarmudji. 2005. Viability of Saccharomyces cerevisiae, Rhizopus oligosporus and their combination in rice powder. Pros Semin Nas Peternak dan Vet. Bogor (Indones): Pusat Penelitian dan Pengembangan Peternakan.

Kusumaningtyas E, Widiastuti R, Maryam R. 2006. Reduction of aflatoxin B1 in chicken feed by using Saccharomyces cerevisiae, Rhizopus oligosporus and their combination. Mycopathologia. 162:307-311. 
Lanciotti R Guerzoni ME. 1993. Competitive inhibition of Aspergillus flavus by volatile metabolites of Rhizopus arrhizus. Food Microbiol. 10:367-377.

Mukherjee R, Chakraborty R, Dutta A. 2016. Role of fermentation in improving nutritional quality of soybean meal - A Review. Asian-Australas J Anim Sci. 29:1523-1529.

Nout MJR. 1989. Effect of Rhizopus and Neurospora spp. on growth of Asergillus flavus and A. parasiticus and accumulation of aflatoxin B1 in groundnut. Mycol Res. 93:518-523.

Ortega-Beltran A, Moral J, Puckett RD, Morgan DP, Cotty PJ, Michailides T. 2018. Fungal communities associated with almond throughout crop development: Implications for aflatoxin biocontrol management in California. PLoS One. 13:e0199127.

Rabinal CA, Bhat S. 2017. Profiling of Trichoderma koningii IAB1252'S secondary metabolites by thin layer chromatography and their antifungal activity. Bioscan. 12:163-168.

Shakeel Q, Lyu A, Zhang J, Wu M, Li G, Hsiang T, Yang L. 2018. Biocontrol of Aspergillus flavus on peanut kernels using Streptomyces yanglinensis 3-10No Title. Front Microbiol. 23:1-9.

Tian F, Chun HS. 2017. Aflatoxin-control-analysis, detection and health risk. Chapter 2. Natural product for preventing and controlling aflatoxin contamination of food. In: INTECH. London (UK); p. 13-44.

Udomkun P, Wiredu AN, Nagle M, Muller J, Vanlauwe B, Bandiopadhyay R. 2017. Inovative technologies to manage aflatoxin in food and feeds and application-A review. Food control. Food Control. 76:127-138.

[WHO] World Health Organization. 2019. Method of sterilization. The International Pharmacopoeia. $9^{\text {th }}$ ed. Geneva (Swiss): World Health Organization; p. 1-3. 